CORRECTION

\title{
Correction to: Salience reasoning in coordination games
}

\section{Julius Schönherr ${ }^{1}$ (D)}

Published online: 15 April 2021

(c) Springer Nature B.V. 2021

\section{Correction to: Synthese https://doi.org/10.1007/s11229-021-03083-x}

The figure legends and figure placement in the original article has been corrected.

Publisher's Note Springer Nature remains neutral with regard to jurisdictional claims in published maps and institutional affiliations.

The original article can be found online at https://doi.org/10.1007/s11229-021-03083-x.

\section{Julius Schönherr}

schoenherrjulius@gmail.com

1 Institute of Foreign Philosophy, Department of Philosophy and Religious Studies, Peking

University, 5 Yiheyuan Rd., Office 223, Haidian Dist., Beijing 100871, China 